\title{
Exploring the Effectiveness of Implementing Seminars as a Teaching and an Assessment Method in a Children's Literature Course
}

\author{
Sharifa Said Ali Al'Adawi ${ }^{1}$ \\ ${ }^{1}$ Rustaq College of Applied Sciences, Borj Alredah, Rustaq, Batinah-South, Oman \\ Correspondence: Sharifa Said Ali Al'Adawi, Rustaq College of Education, Borj Alredah, Rustaq, Batinah-South, \\ Oman. E-mail: sharifa.rus@cas.edu.om
}

\author{
Received: August 112017 Accepted: October 5, 2017 Online Published: October 9, 2017 \\ doi: 10.5539/elt.v10n11p1 URL: http://doi.org/10.5539/elt.v11n10p1
}

\begin{abstract}
The classroom environment should support students' autonomy through teaching and assessment methods. This article highlights students' perceptions about the value of implementing seminars as a teaching and an assessment method in a children's literature course in a college of applied sciences (XCAS). Additionally, preparation considerations and limitations of such implementation are discussed. Findings indicted the positive effects of seminars in enriching classroom learning and students' responsibility for their own learning which can be achieved through training for teachers and students. Practical implications of seminar implementations for future use are outlined and a conceptual framework is suggested based on the findings.
\end{abstract}

Keywords: Socratic seminar, deep learning, action research, effectiveness, learning histories, context

\section{Introduction}

Literature on teaching and assessment highlights current pedagogical issues such as integrating assessment into the learning process, teachers and students' roles in assessment, and the importance of assessment literacy and assessment feedback to achieve effective assessment procedures that can engage students in the assessment process and serve to inform students' performance (Boud, 2014; Boud \& Soler, 2015). Despite the substantial amount of theoretical literature on assessment, reports on what actually works in the classroom is still limited especially in Oman (Al-Badawai, 2011; Al-Issa, 2005, 2011; Al-Mahrooqi, 2012a, b). Aiming to position assessment as an integral part of the teaching and learning process without taking the context of the Omani classroom environment- involving teachers and students' expectations and past experiences- into consideration may have undesirable consequences on the value of assessment, teaching and learning processes. Considering that teaching methods such as lecturing and assessment methods like tests still dominate educational policy and practice in Oman (Al-Hajri, 2014; Al-Issa, 2011; AL-Maskri, Al-Mukhini, \& Amzat, 2012), students' rely on teachers to provide the materials, highlight what is important, plan revisions and manage and lead the lecture time (Al-Badwawi, 2011; Al-Issa, 2005, 2011). Students, therefore, play a passive role in learning as they listen to the teacher, may take notes or just retrieve the materials from the teacher later, usually to review them for the midterm and final exams, which forms not less than $70 \%$ of the course overall grade. However, there has been moves towards a more interactive mode of students working with teachers such as group work, peer feedback, presentations, portfolios and/or seminars. Seminars advocate and support experiential learning where students are contributors in finding truth and forming their own perspective of the truth through experience (Aubrey \& Riely, 2016; Piaget \& Vygotsky as cited in Passarelli \& Kolb, 2011).

This paper aims to investigate the effectiveness of implementing seminars, in a children's literature (CL) course in a college of applied sciences in Oman (X-CAS), on students' active engagement in learning. It aims to answer these three questions:

1). How effective are seminars as a teaching and an assessment method?

2). What are students' perceptions of implementing seminars as a teaching and assessment method in Children Literature course?

3). What are the limitation of such implementation faced by students and the course teacher? 
This paper is organized as follows: section two summarises the literature on the use of seminars and highlights findings of previous studies in the field. Section three explains the context, procedures and ethical issues related to the instruments and participants, while section four reports the results and interprets the finding and finally section five discusses the limitations of the study and recommends directions for future research.

\section{Seminars as a Teaching and a Learning Method}

Seminars have been used as a teaching method since Socrates for their value in engaging students in the teaching and learning process. Socrates did not teach explicitly but created situations and raised questions that require students to think and analyse using their higher level thinking skills to understand the underlying meaning of Socrates words. Socrates' classes have promoted intellectual curiosity, independent learning and involved students as a valuable source of knowledge-sharing using their background knowledge to find 'the truth' (Bates, 2016). Thus, students are viewed as contributors in shaping reality and finding truth by bringing their experience, identity, and values into the learning and teaching process (Dewey's principles, cited in Bates, 2016). Dewey's Principles emphasise that teachers should not spoon-feed knowledge to their students but create opportunities for experience in which students interact, form and reflect on their knowledge with the help of teachers working as facilitators and guides, which in turn supports students 'active engagement (Weber, Gabbert, \& Patrick, 2007).

Additionally, seminars promotes critical reading and writing skills as participants read a wide range of sources and synthesize data that serves the purpose of the seminar (Padgett, Keup, \& Pascarella, 2013; Playmouth, 2011). Moreover, they provide a platform for researchers, teachers or students to share their findings of research and present it in public while receiving regular feedback from the attendees through discussion. As a result, it increases participants' knowledge of other's research findings and create an intellectual atmosphere in the work or study place and thus ensure keeping participants up-to-date with the current issues in the field of discussion (Illinois, 2015). Consequently, communication, management and presentation skills are improved through facilitating and attending seminars and for those attendees of seminar, who are not fans of reading, it offers a great way of gaining information (Chowning, 2009; Polly, Fraizer, Hopper, Chaman, \& Wells, 2012).

Seminars have been investigated for their effectiveness in different fields: education, medicine, business, and at different levels: school, university or professionals. For example, support seminars helped in-service teacher to become more effective teachers (Weber, Gabbert, Kropp, \& Pynes, 2007). They can also scaffold and prepare preservice teachers for their teaching careers as it has been found that the support seminar group was well-equipped and prepared for teaching better than a comparison/ control group, which has not received support seminars (Polly, Fraizer, Hopper, Chaman, \& Wells, 2012). In addition, seminars are convenient for professionals, who needs to be up-to-date in their field, need a platform to discuss issues and concerns and have less time to do all of the research on their own. Yildirim (2010), for instance, investigated increasing effectiveness of strategic planning seminars through learning styles. School principals were required to write strategic plans via getting together in a seminar. They evaluated their schools current status (via SWOT: strengths, weaknesses, opportunities \& threats) and planned accordingly. The seminar effectiveness was increased by taking into account the participants' learning styles as school principals planned their schools' strategic plans taking into account their preferences, weaknesses and strengths, which made their strategic plans accessible and practical (Yildirim, 2010). To sum up, seminars can have positive effects on different individuals and for different fields taking objectives of seminars and the particular field into account.

\subsection{Seminars Modes of Implementation}

Moreover, seminars can be implemented as a face-to-face or virtual mode. Socratic seminars, for example, were a form of face-to-face seminars, while Murray, Giesbrecht and Mosonyi (2011) E-learning course, where students' interact via an online space, is a virtual mode of seminar. Students have shown active and enthusiastic participation in the virtual seminar completing each other's thoughts, supporting each other and easing fears and concerns of their peers (Murray, Giesbrecht, \& Mosonyi, 2011). Teachers feared that students might lose the essence of face-to-face interaction and social relationships promoted by facial expressions, gestures and laughter that students develop sitting next to each other in the few minutes before the beginning of the class. However, this was overcome by creating a social platform in which students exchanged information about their identity, likes and dislikes and thus came to know each other and even formed relationships (Chowning, 2009; Murray, Giesbrecht, \& Mosonyi, 2011). Other forms of face to face seminars are those frequently used in medicine for students and professionals. For instance, Dahiya and Dahiya (2015) investigated the effectiveness of classroom seminars and journal club (CRSJC) as a teaching learning tool on postgraduate pharmacy students. The feedback of the participants were highly responsive and positive, and students showed extraordinary performance in their seminars and discussions. Moreover, Doane and Boyd (2016) explored the effectiveness of a symposium-based 
self-directed learning approach to teaching medical Cell Biology to medical students. Findings indicated symposiums real value in improving students' skills not only in knowledge. It improved students' search, presentation, and interpretation and communication skills, and thus promoted their self-regulated learning. Both face-to-face and virtual mode of seminars can be successful yielding positive effects in enriching knowledge and skills if implemented well.

\subsection{It Could Go Wrong}

However, seminars do not always work as planned. For instance, in a study investigating students' perception of teaching and assessment methods in pharmacology in an Indian university, Badyal, Bala and Kthuria (2010) found that only one third of the participants were satisfied with seminars as a teaching and assessment tool. One third of the participants disliked seminars due to the effort they have to put into the preparation and presentations of seminars, which can be a burden with other courses requirements. In addition, if students are not trained well on leading seminars, they might just memorise, cram information, and present them without deep understanding of the topic (Spruijt et al., 2013). Therefore, to achieve the full potential of seminars, students should be aware of the rationale behind this method of teaching and assessment and their role in it. It is also essential to have a clear plan and guidelines on the preparation, steps, criteria and teachers' role as facilitators of learning in seminars. Therefore, training students, professionals, participants on seminar preparation and participation is necessary. Preparation involves the wide range of readings, raising questions and participating in the seminars or practical issues such as venue for seminars and time (Gibson, 2010; Plymouth University, 2011)

In short, seminars can be used in a variety of ways as a tool for teaching, assessment, support or both. Implementing seminars requires careful consideration of seminars' success factors as rationale, time, organization, resources, criteria for implementation and evaluation, effort needed, medium (virtual or physical environments) and students' learning styles (Gibson, 2010; Spruijt et al., 2013).

\section{Methodology}

An action research design was adopted to investigate the three questions to improve the educational practices at XCAS by enhancing understanding of the researched issue and resulting practical strategies devised to improve the system (Koshy, 2010). This action research implemented two methods of data collection: observation and questionnaires. Observations took place throughout the semester during Children's Literature (CL) lectures by the teacher of the two groups. The questionnaires were generated and data collected using google forms in the final week of the academic semester-15 weeks (see Figure 1).

This research fits within the constructivist world views of reality and knowledge as it emphasise that knowledge and truth does not exist in an external world detached from the participants, but it is actually constructed by the participants through dialogue and experience (Gray, 2013). Thus, reality is constructed not discovered and it is generated by experience. This world view of truth and knowledge supports values of sharing and communicating to construct knowledge, and thus participants' contributions are valued and central to research (Gray, 2013). Action research is one method that places emphasis on the close collaboration between the researcher and the participants to promote change within institutions such as schools/colleges (Gray, 2013). Therefore, implementing seminars as a method to enhance learning and effectively evaluate learners' performance adopts the action research to promote change in the learning and assessment process. 


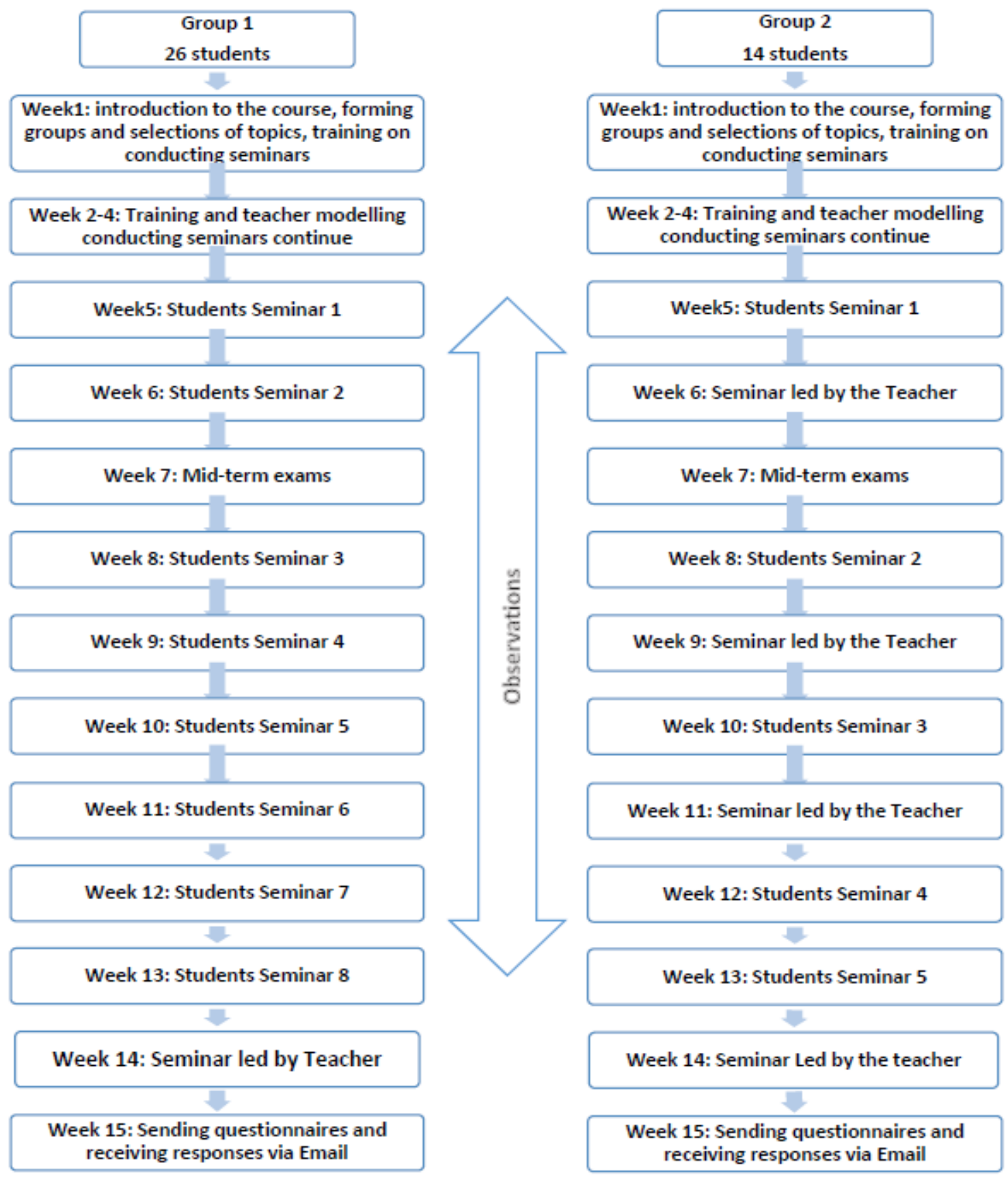

Figure 1. Study intervention and data collection

The participants were second year male and female students, aged 19-21, from the teacher trainee programme at X-CAS (name of the college when the study was conducted), Oman. There were 26 students in one group and 14 in the other. The distribution of the students in the two groups was the results of students signing up for the group they chose for which the researcher had no impact on. The teacher trainee programme is a four years bachelor degree programme preceded by 1-2 year/years foundation programme. The participants registered for the CL course in their second year of the major. CL is one of four courses of literature- Literature I, Literature II, Children Literature, and World Literature- and is designed to explore Children Literature genres and how they can be taught in children schools. It is run for a whole semester of 15 weeks. This study was conducted in spring 2015. Lectures, tutorials and seminars were the main mode of teaching. Students were assessed on seminars presentation $(10 \%)$, report on seminars $(10 \%)$, midterm test $(30 \%)$ and final exams $(50 \%)$. 
On the first day of the 15 weeks semester, the teacher of the class (researcher, as it is an action research) provided an overview of the course explaining to students the objectives, teaching mode and assessment procedures of the course. Students were informed that they would be required to prepare for a seminar instead of a topic presentation. They were told they would have to raise questions and organize discussions in which the audience has a very important role. Students were assured that the first weeks of instruction would provide training on the seminar preparation and that students' seminars would only begin in week five. Therefore, students had more than a month to prepare for the first group seminar. Then, students assigned themselves to groups of 2-4 students and chose the genre and the week they were going to present in, based on the course structure (Appendix A). Students were told that they could seek help from the teacher or friends if they confronted any challenges. In addition, students were given training on preparing and presenting seminars in the first four weeks of the semester by the teacher explaining as well as modelling seminar presentation for the first three weeks' topics/genres of Children Literature specified in the course description. The class setting was changed to circles or squares where students could face each other, texts were distributed and questions were raised.

Students' seminar presentations started in weeks five to 13/ in group A, which had 26 students and students led seminars every week. However, in group B (14 students) seminars were led by students in five weeks of the semester only (Week 5, 8, 10,12\& 13) and the class teacher presented the rest of the weeks due to the small number of students in this group (as indicated in Figure 1).

Data were collected via observation and questionnaires. The class teacher observed every presentation and encouraged the students' audience to raise questions and give feedback on and raise questions about their peers' presentations. Observations provided a rich account of data for analysis and in-depth insights (Blandford, 2013) of seminar. However, it was sometimes impossible to observe everything. It was, also, difficult to analyse all behaviours (Blandford, 2013; Creswell, 2014), as humans are complicated creatures. Affective, cognitive and environmental factors all contribute to affect their behaviours. Moreover, students' seminar presentations were assessed based on a rubric (Appendix B), which was adapted from North Dakota State University Plant Science course (2015) for seminar evaluation. The adapted seminar rubric focused on three skills such as students' skills on discussing subject matters, presentation skills, and asking and answering questions, which were suitable for a CL course. The use of rubrics provided a constant guide on the criteria (consistency) that should guide students' performance and evaluation especially if they are analytic and topic specific (Brookhart, 2013; Jonsson \& Svingby, 2007). It was also an attempt to offer a fair evaluation of students' performance regardless of previous evaluation of each student level. Furthermore, questionnaires were sent to the students' college email via google forms in the last week of teaching (week 15), after all students presented their seminars and before the final exams (week 16), and answers were received in the same week (week 15). The questionnaire constituted of 37 multi-items scale that requested from participants to rate the items on a five-category scale ranging from $1 /$ totally disagree to $5 /$ totally agree (Table 1 ). Twenty-nine students of the 40 participants in the study answered the questionnaire. The use of questionnaires offered the advantage of gathering as much information as possible in a short time (Brown, 2011; Creswell, 2014). In addition, Google forms provided presentable formats of the questionnaire and helped perceive the questionnaire from getting destroyed or being lost. It also helps present responses in graphs and charts (Randall, 2013).

Ethical issues were discussed fully with the participants and ethical consent sought in line with the Omani Ministry of Higher Education (MOHE) current practice at the time of the study. The two groups of students were informed of the change in the assessment with regard to the seminar and were informed of the objectives of such change. They were consented on the use of the data for research purposes only and were asked for their voluntary participation in the survey and that withdrawing from the study meant receiving the treatment but their data would be excluded from analysis. They were assured that their identities were not going to be revealed. Additionally, the validity of the questionnaire, designed and tested by the researcher, was validated via going through the items with the students to check their understanding of the meaning and clarity (teacher-administered). However, a panel of experts used or Cronbach alpha might have been a better validating procedure.

\section{Results and Discussion}

The effectiveness of the implementation of seminars as a teaching and an assessment method in a CL course was evaluated by a seminar rubric, teacher observation and students' responses to a questionnaire distributed in week 15 of the academic semester. While students' performance was evaluated by the seminar rubric, observations elaborated more on seminar participants' behaviours and questionnaires explored their perception of the method and of their own performance in seminars. 


\subsection{Seminar Rubric}

As seminar Rubrics are designed to guide students on what is important and by which criteria they will be assessed (Brookhart, 2013; Jonsson \& Svingby, 2007), the Children's Literature seminar rubric was developed to assess students on:

\section{No Criteria}

1 Subject Matters $/ 3$ (Definition and types, origins and characteristics)

2 Presentation /4 (Techniques, organization, language and visual/audio aids)

3 Questions and Discussion $/ 3$ (Leading questions, promoting and handling questions) as shown in (Appendix B).

However, many seminar presentations indicated little attention is paid to the assessment rubric. Weeks 5-9 of students' presentations showed that seminar leaders overlooked the origins of the genres and how to promote and encourage questions during seminars. This can be attributed to the low weight of assessment allocated for the seminar presentation $(10 \%)$ or to ignoring the assessment rubric altogether although students had the pdf guide to Children Literature course in which instruction, assessment rubric, course description and group presentations and timing were stated clearly. However, seminars leaders of presentations of weeks 10-12 were much better on following the assessment rubric as they benefited from teachers and students feedback on previous seminars.

\subsection{Observations}

Observations yielded in-depth insights of the process (Blandford, 2013; Creswell, 2014) within each seminar as well as providing the opportunity to compare and contrast between the various seminars taking into account the limited, restricted and subjective view and ability of the teacher (Blandford, 2013). Starting from week 5 in Spring 2015, the teacher assumed the role of an observer and facilitator to the seminars' discussion. Different themes emerged from the observations note-analysis such as sensitivity to context, participants' roles during seminars and participants' learning histories, seminar's preparedness and flipping classrooms, training participants on giving feedback, deep learning and availability of resources such as space and materials.

First, sensitivity to context and participants' learning histories is a key factor to the success of seminars and it is is essential to ensure its inclusivity to all participants. It was obvious that seminar leaders preferred arranging their classmates (participants) in groups of 4-5 participants in each group. They did not prefer the whole class circle or square as they thought it inhibited students' participation and created an uncomfortable atmosphere. When presenters were a bit adventurous in terms of classroom setting arrangements and they arranged seminar participants in a whole class group, students were less willing to participate. The reason for this is that culturally, girls are not in much contact with boys unless necessary, as well as participants' learning histories which indicated that their school teenage years were spent in single-gender schools and thus students tended to work and pair with classmates of the same gender. Therefore, awareness of learners' educational histories and particularities of the context is significant for the success of any new teaching or assessment techniques.

Second, intensive training and discussion of seminars' value is important for deep internalisation and understanding of seminars. Most of the group presenters acted like teachers not as seminar leaders. They assumed their roles as micro-teachers presenting every interesting idea and asking mechanical repeated questions such as theme, characters and plot of the story. They did not ask thought-provoking questions and the audience participation was limited to answering the questions raised by seminar leaders. They did not come up with their own questions or raise points in regard with the seminar topic. The last group of presenters in group A, however, was the only group that really took serious steps as seminar leaders. This was obvious in terms of the setting of the audience in a big square, questions were raised about the text that provoked audience thought, which were not spoon-fed by the leaders from the beginning and they required students' participations. Students' misconception of the nature and purpose of seminars can be interpreted as a result of a lack of training. That is to say the first week of explaining the nature and objectives of seminars and the following three weeks of implicit modelling of seminars were not enough to internalise the concept of seminars and promote deep learning.

Third, participants exerted limited critical thinking effort, which can be overcame via the notion of flipped classrooms. Students raised the same questions for almost every genre of Children Literature. Those questions were related to story elements such as topic, theme, characters, plot and end. This indicated that students were not making the required mental effort or they did not understand what they were really supposed to do. Moreover, this limited critical thinking effort may be due to the limited time of the class (one hour and 40 minutes) as they received, read and questioned the short texts in class. Sending the materials before class would have been a better solution to give students time to read the materials, however, as the teacher tried that technique during the 
training weeks to no avail, class time was used to read and discuss the materials. Therefore, it would be better to choose the texts, send them to the students earlier in the semester, and train students to read and prepare them out of class time (Flipped classroom). This means classroom time will be devoted for discussion and activities and that leaders need to do their preparations in terms of selecting the texts earlier in the semester, as they are responsible for selecting and sending the materials to the students' audience. Flipping classroom can encourage critical thinking and help exploit classroom time to achieve the objective of seminars.

Fourth, promoting awareness of criteria of excellence and training participants in giving feedback is significant to scaffold participants' roles in seminars. The majority of the seminar participants assumed the role of supporters by giving constant good feedback such as a very organized presentation, good selection of stories or clear voice. This showed that these students either were just giving feedback on the surface element of the seminar, format and tone, neglecting its effect on encouraging critical thinking, or they wanted support back from their classmates during their own presentations. However, there was one student who always tried to trick presentation leaders and prove them wrong especially girls. His attitude clearly indicated that he was not aware of the purpose of seminars or he may have thought that proving others wrong, made him look more knowledgeable and competent. The teacher had to step in, in few occasions when he took it far and made seminar leaders seem tense. Again, this may be due to the lack of training and participant misunderstanding of criteria of excellence which has been explained during the training weeks.

Fifth, Logistics such as seminar space/venue does matter to have a successful seminar. Some presentations suffered from the impracticality of the available space as group A has to present their seminars in a classroom where a column scaffolding the roof offered an obstacle separating some students from the vision range of the presenters and the rest of the students. This group was bigger in number (26), however, there was no alternative as all other rooms were occupied at the time of the lecture. In addition, trying to change lecture time was a challenge as the new suggested slot hour always clashes with students' lectures timetables. Therefore, the only solution was to make the most of the available room with the column. This, however, had its effect on the setting arrangement of the seminar group and on the seminar presenters' performance as they did complain of the unsuitability of the classroom. Thus, there should be enough space for a successful implementation of seminar discussions.

To sum up, observation raised key issues (Blandford, 2013) related to implementing seminars as a teaching and an assessment method in the classroom; issues that would have been hard to deduct through questionnaires only such as participants' management of seminars, sensitivity to context as in mixed-gender group discussion discomfort, the importance of training, the sort of questions raised by seminar leaders and audience. Observations indicated these elements that needs to be considered for future implementation such as setting and time as some participants did the minimum in terms of time and effort requirements in order to pass, while others put a lot of effort and time on their seminar presentation and thus the amount and depth of knowledge presented was clear. Generally, males groups exerted less effort than Females.

\subsection{Questionnaires}

Table 1 presents the responses gathered from the questionnaire with regard to students' perceptions of seminars. The questionnaire was designed, piloted, sent and data gathered during week 15, the last week of teaching. The questionnaire responses were categorised into knowledge of and experience with seminars, benefits of seminars and satisfaction with and willingness to participate in future seminars.

Findings indicated that less than half of the participants were aware of the value of seminars, which calls for intensive training. Seventeen out of 40 participants confirmed that they knew (11 slightly agreed +6 totally agreed) the purpose of seminars while one student totally disagreed. However, 17 out of 40 students stated that they needed more clarification on seminar preparation and six students stated that the teacher was not very informative when she explained seminars, which indicates a need for explicit instruction on seminars. Moreover, 23 participants confirmed that CL was their first experience with seminars and consequently 20 out of 4o participants reported that preparing for a seminar requires a lot of time and effort especially because there was a lack of resources as stated by 14 participants. Some of these students consulted the teacher on the resources they should use and what stories they should apply for group analysis. The teacher tried to guide students on research tips and useful resources that could offer the wide range of reading required for a successful seminar presentation (Gibson, 2010; Plymouth, 2011). Therefore, adequate training is required to raise students' awareness of seminars and how to deliver a successful seminar (Gibson, 2010; Spruijt1 et al., 2013).

Furthermore, about half the participants indicated the positive effects of seminars on their knowledge and skills. For example, 19 out of 29 students stated that their research skills improved, 21 suggested it encouraged 
teamwork and 17 confirmed its usefulness in developing students' autonomy. These were some of the reasons behind implementing seminars in classroom teaching and assessment as it is believed that it helps change students' role from passive listeners to active engaged participants who share their experience in order to shape their own knowledge and find truth (Bates, 2016). This was indicted by 21 students who thought that discussions were fruitful and 22 students thinking that seminar contributed to enrich their understanding of the presented topic. Moreover, seminar had also an effect on students' skills not only their knowledge of the topic (Padgett, Keup \& Pascarella, 2013) as 20 students agreed the seminar helped them practice explaining and clarifying their ideas. Seminars positively affected the majority (23) of students' communication skills and 21 students' critical thinking and questioning skills by sharing ideas and learning from others (Yildirim, 2010). However, the positive effect of seminars were compromised by some behaviour adopted by minority of students like trying to prove others wrong as a way of showing their superiority, which was confirmed by twelve students, while 12 others thought that their classmates were supportive. Despite the value of supportive participants in seminars, some students were over-supportive indicating only positive feedback regardless of how untrue and exaggerated they were. This may be due to misconception on what constitute supportive participation. Others, however, were very supportive in terms of active participation trying to keep the flow of discussion (Spruijt et al., 2013)

Table 1. Students' perceptions of the effectiveness of seminars

\begin{tabular}{|c|c|c|c|c|c|c|}
\hline \multirow[t]{2}{*}{ No } & Statement & $\begin{array}{l}\text { Totally } \\
\text { disagree }\end{array}$ & $\begin{array}{l}\text { Slightly } \\
\text { disagree }\end{array}$ & Neutral & $\begin{array}{l}\text { Slightly } \\
\text { agree }\end{array}$ & \multirow[t]{2}{*}{$\begin{array}{l}\text { Totally } \\
\text { agree }\end{array}$} \\
\hline & & \multicolumn{4}{|c|}{ Number of students } & \\
\hline 1 & $\begin{array}{l}\text { I have previously participated or } \\
\text { organized a seminar. }\end{array}$ & 10 & 5 & 4 & 5 & 5 \\
\hline 2 & I know the purpose of seminar. & 1 & 4 & 7 & 11 & 6 \\
\hline 3 & $\begin{array}{l}\text { I need more clarification in terms of } \\
\text { seminar. }\end{array}$ & 4 & 4 & 4 & 12 & 5 \\
\hline 4 & $\begin{array}{l}\text { CL teacher was not very informative } \\
\text { when she explained seminars. }\end{array}$ & 5 & 9 & 9 & 5 & 1 \\
\hline 5 & $\begin{array}{l}\text { My first experience with seminar was in } \\
\text { CL Course. }\end{array}$ & 4 & 0 & 2 & 2 & 21 \\
\hline 6 & Preparation for seminar takes time. & 2 & 1 & 6 & 11 & 9 \\
\hline 7 & $\begin{array}{l}\text { There are not enough resources for } \\
\text { organizing a seminar. }\end{array}$ & 2 & 5 & 8 & 12 & 2 \\
\hline 8 & Seminars improved my research skills. & 1 & 3 & 6 & 10 & 9 \\
\hline 9 & It encourages teamwork. & 1 & 1 & 6 & 6 & 15 \\
\hline 10 & It develops students' autonomy. & 1 & 0 & 11 & 9 & 8 \\
\hline 11 & $\begin{array}{l}\text { I am quite satisfied with my } \\
\text { performance as a seminar organizer. }\end{array}$ & 0 & 2 & 10 & 14 & 3 \\
\hline 12 & $\begin{array}{l}\text { I am quite satisfied with my } \\
\text { performance as a participant in CL } \\
\text { seminars. }\end{array}$ & 1 & 3 & 8 & 11 & 6 \\
\hline 13 & I learnt that discussion is fruitful. & 1 & 2 & 5 & 13 & 8 \\
\hline 14 & I have benefited from seminars. & 1 & 1 & 7 & 11 & 9 \\
\hline 15 & $\begin{array}{l}\text { It contributed to my understanding of } \\
\text { the topic. }\end{array}$ & 0 & 1 & 6 & 13 & 9 \\
\hline 16 & $\begin{array}{l}\text { I have applied knowledge I have gained } \\
\text { from a wide range of readings. }\end{array}$ & 1 & 3 & 9 & 11 & 5 \\
\hline 17 & $\begin{array}{l}\text { It helped me clarify concepts through } \\
\text { discussion. }\end{array}$ & 0 & 1 & 5 & 15 & 8 \\
\hline
\end{tabular}




\begin{tabular}{|c|c|c|c|c|c|c|}
\hline 18 & It corrected misunderstanding of ideas. & 2 & 3 & 4 & 13 & 7 \\
\hline 19 & I practiced explaining myself & 0 & 5 & 4 & 11 & 9 \\
\hline 20 & It encouraged practicing literary terms. & 0 & 2 & 7 & 14 & 6 \\
\hline 21 & $\begin{array}{l}\text { It encouraged sharing ideas and learning } \\
\text { from others. }\end{array}$ & 1 & 0 & 5 & 7 & 16 \\
\hline 22 & $\begin{array}{l}\text { The amount of information discussed in } \\
\text { seminars is huge. }\end{array}$ & 1 & 2 & 9 & 8 & 9 \\
\hline 23 & $\begin{array}{l}\text { A whole group discussion is better than } \\
\text { lecturing. }\end{array}$ & 1 & 3 & 4 & 7 & 14 \\
\hline 24 & $\begin{array}{l}\text { Questions are raised and discussed } \\
\text { during seminars. }\end{array}$ & 1 & 0 & 4 & 16 & 8 \\
\hline 25 & $\begin{array}{l}\text { There is more space for critical thinking } \\
\text { in seminars. }\end{array}$ & 0 & 1 & 7 & 16 & 5 \\
\hline 26 & $\begin{array}{l}\text { Students are more engaged and active in } \\
\text { seminars than in lectures. }\end{array}$ & 1 & 4 & 4 & 15 & 5 \\
\hline 27 & $\begin{array}{l}\text { Students try to prove others wrong } \\
\text { during seminars. }\end{array}$ & 3 & 7 & 7 & 9 & 3 \\
\hline 28 & $\begin{array}{l}\text { Students are happy and supportive } \\
\text { during seminars. }\end{array}$ & 2 & 5 & 12 & 8 & 2 \\
\hline 29 & Seminars are just like micro-teaching. & 5 & 9 & 8 & 5 & 2 \\
\hline 30 & $\begin{array}{l}\text { There is not any difference between } \\
\text { lecturing and seminars. }\end{array}$ & 9 & 6 & 8 & 3 & 3 \\
\hline 31 & $\begin{array}{l}\text { Post-seminar questions and feedback } \\
\text { are informative. }\end{array}$ & 1 & 4 & 6 & 6 & 12 \\
\hline 32 & $\begin{array}{l}\text { My classmates were encouraging and } \\
\text { supporting. }\end{array}$ & 3 & 5 & 9 & 7 & 5 \\
\hline 33 & $\begin{array}{l}\text { I owe my seminar successes to good } \\
\text { preparation. }\end{array}$ & 0 & 1 & 6 & 16 & 6 \\
\hline 34 & $\begin{array}{l}\text { I owe my seminar successes to } \\
\text { teamwork. }\end{array}$ & 1 & 1 & 3 & 15 & 9 \\
\hline 35 & $\begin{array}{l}\text { I owe my seminar successes to } \\
\text { classmates'participation. }\end{array}$ & 0 & 5 & 10 & 10 & 4 \\
\hline 36 & $\begin{array}{l}\text { I am willing to organize another } \\
\text { seminar again. }\end{array}$ & 4 & 2 & 7 & 7 & 9 \\
\hline 37 & I think my group seminar was good & 0 & 1 & 9 & 10 & 9 \\
\hline
\end{tabular}

Furthermore, the majority of students showed positive reactions towards their own performance in CL seminars with 17 students quite satisfied with their seminar organization skills in particular and their participation in the seminar in general and 19 students rated their performance as good.

However, six students thought that there was no difference between lecturing and seminars modes of teaching and seven students thought seminar was just like microteaching which could be the source of dissatisfaction with their performance. This is applicable to most of the seminars organized by the students as students did not really understand the objectives of the seminar or they did not have enough training on conducting seminars. Therefore, students' seminars were more like lecturing or micro-teaching, which calls for explicit explanation of the difference between these three modes of teaching. Students' perception and satisfaction with seminars is also indicated by their willingness to organise seminars again. Unfortunately, only 16 students expressed interest in organizing seminars. These students were probably the students who stated that seminars improved them intellectually and skilfully indicating that the wide selection of readings in preparation for the seminar had its positive effects in their understanding of the topic. It had its positive influence on their communication and 
clarifications skills as well. However, eight students indicated their unwillingness to organize seminars probably because they thought it was another micro-teaching, because of the effort and time required for preparation and organization of seminars (Badyal, Bala \& Kathuria, 2010), or simply because it does not cater or correspond with their learning preferences as some learners prefer working on their own.

Analysing the data gathered by the questionnaire, however, indicated that the questionnaire items should have been validated by a panel of experts or piloted by a group of students from the second year of the programme. The teacher read the questionnaire items at lecture time and asked students whether they understand the statement or not and they all confirmed they understood. Moreover, Children Literature seminar students' perception questionnaire needs to be tested for reliability using Cronbach alpha as some statements were positive (e.g. statements $1,2,15 \& 19$ ), while others were negative statements (e.g. statements $4,7, \& 30$ ) which affect questionnaire reliability. In addition, the analysis of the data indicated repetition of similar statements, which might have caused confusions such as $(28 \& 32) \&(17 \& 18)$, so clearly the questionnaire design needs further effort to make it sound.

Discussion of results of this study represented in the emerging themes such as context, learning histories, feedback, criteria of good work, deep learning, classroom environment, and instruction, led to the construction of the framework of seminar as a teaching and an assessment method (Figure 2).

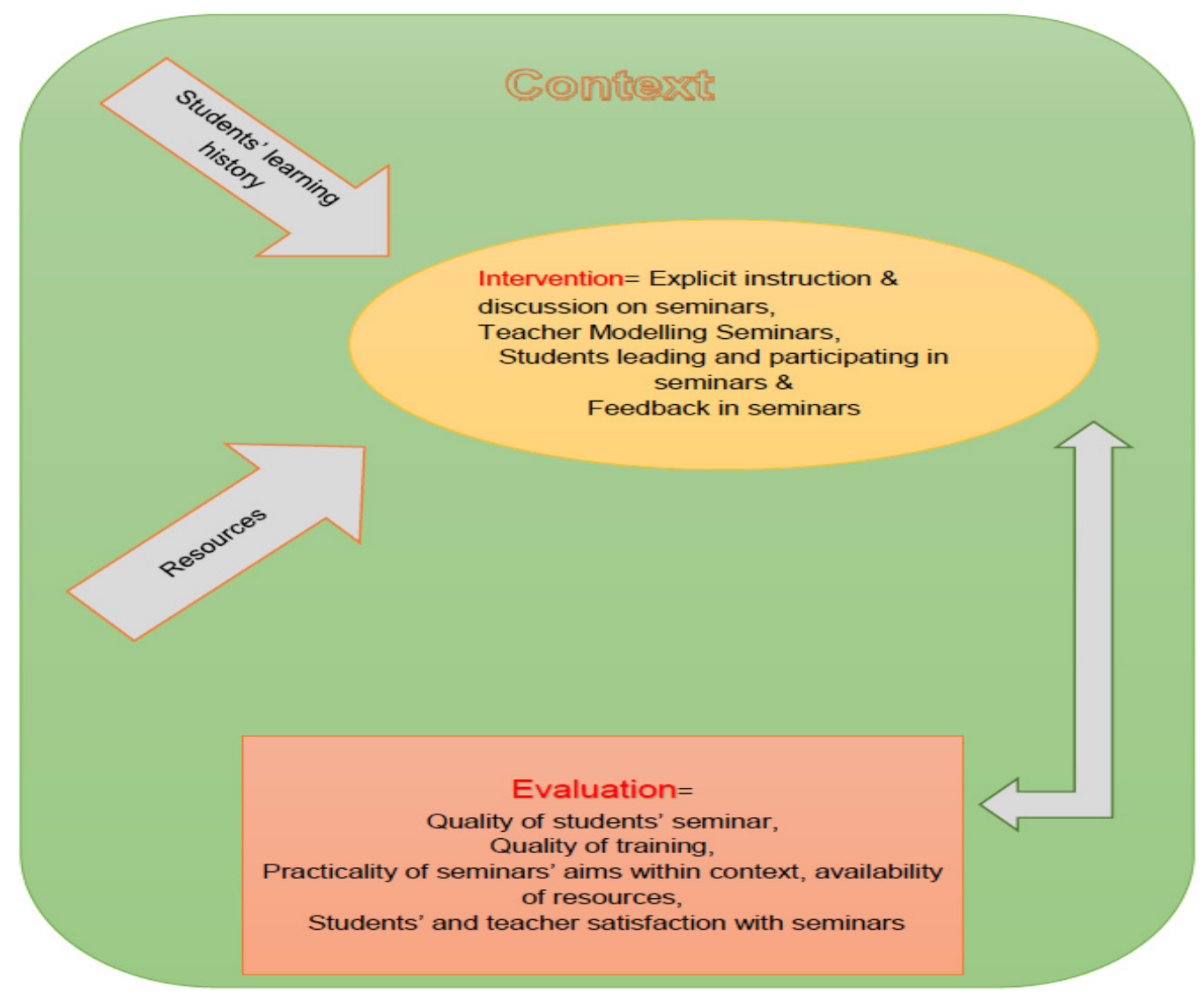

Figure 2. Seminar as a teaching and an assessment method framework

Seminar as a teaching and an assessment method framework (Figure 2) indicates the sensitivity to context as a significant factor in the success of seminars. Context is represented in the resources available to the teacher and students, the instructor's teaching style, learner's learning histories and learning preferences, the learning resources and the physical environment. Resources, for instance, are those related to the classroom materials and seminar environment. Materials should be adequate to support a deep discussion of a particular topic/genre and the environment/venue should support creative implementation and effective discussions of seminars. Moreover, the teaching style and learning preferences should be considered before implementing seminars. That is to say first implementation of seminars requires training teacher and students in participating in seminars, which 
involves awareness of seminars objectives and benefits as well as the steps required for a successful seminar. Additionally, successful implementation of seminars requires considering learners previous experiences and learning styles as forcing all students to adopt a certain procedures and neglecting their learning histories may be counter-productive. Thus, discussion of learners' previous experiences and potential benefits of seminars is essential before utilising seminars as a teaching, a learning and an assessment method.

Moreover, the actual implementation of seminars requires a period of training that involves explicit instruction, discussion and modelling of seminars. In this period learners become familiar with seminars and their value for deep learning, become familiar with the criteria of excellence, observe exemplar of good seminar, learn how to use feedback and provide feedback to their classmates. Learners construct the meaning of seminars during the training period, which extended for three weeks of modelling in this study but may be expanded to a longer intensive period to familiarise students with such a method of teaching especially if they have limited previous knowledge and experience of seminars. Students then conduct seminars on pre-decided topics, receive feedback from their teacher and classmates and later write reflection of their own performance highlighting areas for improvement.

Furthermore, evaluation of seminars success involves different factors such as quality of participants' seminar, quality of training, practicality of seminars' aims within context, availability of resources, participants' and evaluator/teacher satisfaction with seminars. Quality of participants' seminars are evaluated via the criteria explained and given to the students (Appendix B) and they tackled quality and scope of content, quality of presentation and delivery, quality of questions asked, stimulated and handled, which may indicate participants' engagement and understanding. Quality of training is observed through participants' seminars presentation and by answering the questionnaire, which also indicated participants' satisfaction or dissatisfaction with the training, their performance and the environment in which seminars were conducted. Seminars were also evaluated through participants' reflection sheets of their seminar presentation topics and of their performance.

To sum it up, gathering data using a combination of methods, observations and questionnaires, had a positive influence on the data as they contributed to understand the different aspects, benefits and challenges of implementing seminars as a teaching and an assessment method. While questionnaires were efficient and economical in terms of time and resources, observations provided in-depth account of the implementation interpreting students' behaviours and recommending adaptation for future research. Both, questionnaires and observations, helped construct a framework to help implement seminars successfully.

\section{Conclusion}

This paper presented the findings interpreted from data gathered using observation and questionnaire to investigate the effect of implementing seminars as a teaching and an assessment method in a Children's Literature course and investigate students' perception of the effectiveness of such implementation. The majority of students perceived seminars as a good method of teaching that engaged them actively in critical thinking by raising questions on literary texts, sharing ideas and improving their communication and presentation skills. Lack of training and awareness of the effectiveness of seminars in engaging students in learning, as well as insensitivity to context, participants' learning histories and oversight of the significance of considering logistics in seminars are some of the limitations of this study. Additionally, study instrument/data collection methods could benefit from a better validation procedures such as a panel of experts or Cronbach alpha. Seminars are useful to scaffold deep learning and are recommend for courses that requires discussion and critical thinking. Therefore and for future research, this study recommends considering the framework of seminars as a teaching and an assessment method which lay emphasis on, but is not limited to, an intensive training programme in seminars- including instruction, discussion and modelling of seminar presentation, criteria and evaluation- for a successful implementation of seminars. Moreover, paying special attention to the logistics not only the content and procedures of seminars is likely to yield more positive results.

\section{Acknowledgment}

This work would not have been possible without the support of the college of applied sciences where it was conducted and I am especially indebted to the students who participated in the study and showed commitment for a period of four months.

I am, also, grateful to Prof. Carol Evans for her support and encouragement represented in reviewing the paper and providing constructive feedback throughout the different drafts of the paper.

\section{Reference}

Al-Badwawi, H. (2011). The Perceptions and Practices of First Year Students' Academic Writing at the Colleges 
of Applied Sciences in Oman. Unpublished PhD Thesis. Leeds, UK.

Al-Hajri, F. (2014). English Language Assessment in the Colleges of Applied Sciences in Oman: Thematic Document Analysis. English Language Teaching, 7(3), 19-37. https://doi.org/10.5539/elt.v7n3p19

Al - Issa, A. (2005). The Implications of the Teacher Educator's Ideological Role for the English Language Teaching System in Oman. Teaching Education, 16(4), 337-348. https://doi.org/10.1080/10476210500345656

Al-Issa, A. (2011). Advancing English Language Teaching Research in Gulf Cooperation Council States Universities. MJAL, 3(2), 60-77.

Al-Mahrooqi, R. (2012a). English Communication Skills: How Are They Taught at Schools and Universities in Oman? English Language Teaching, 5(4), 124-130. https://doi.org/10.5539/elt.v5n4p124

Al-Mahrooqi, R. (2012b). A Student Perspective on Low English Proficiency in Oman. International Education Studies, 5(6), 263-271. https://doi.org/10.5539/ies.v5n6p263

AL-Maskri, M., Al-Mukhini, s., \& Amzat, I. (2012). Improving Education System In Oman Through School, Curriculum, Teaching Methods and Evaluation: What Is Needed? OIDA International Journal of Sustainable Development, 3(10), 39-60.

Aubrey, K., \& Riley, A. (2016). Understanding and Using Educational Theories. London, England: Sage publications.

Badyal, D. K., Bala, S., \& Kathuria, P. (2010). Student Evaluation of Teaching and Assessment Methods in Pharmacology. Indian Journal of Pharmacology, 42, 87-91. https://doi.org/10.4103/0253-7613.64502

Bates, B. (2016). Learning Theories Simplified. London, England: Sage Publication.

Blandford, A. (2013). Semi-Structured Qualitative Studies. In M. Soegaard, \& R. F., Dam (Eds.), The Encyclopaedia of Human-Computer Interaction, (2nd ed). Aarhus, Denmark: The Interaction Design Foundation. $\quad$ Retrieved

from

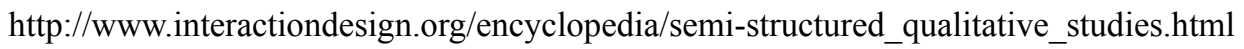

Boud, D. (2014). Shifting Views of Assessment: from Teacher's Business to Sustaining learning. In C. Kreber, Anderson, N. C. Entwistle, \& J. McArthur (Eds), Advances and Innovations in University Assessment and Feedback (pp. 13-31). Edinburgh, England: Edinburgh University Press. https://doi.org/10.3366/edinburgh/9780748694549.003.0002

Boud, D., \& Soler, R. (published online 2015, February 10). Sustainable Assessment Revisited, Assessment and Evaluation in Higher Education.

Brookhart, S. (2013). How to Create and Use Rubrics for Formative Assessment and Grading. USA: ASCD publications. Retrieved from http://www.ascd.org/publications/books/112001/chapters/What-Are-Rubrics-and-Why-Are-They-Important $\% \mathrm{C} 2 \% \mathrm{~A} 2$.aspx

Brown, J. (2011). Statistics Corner: Questions and Answers about Language Testing Statistics: Likert Items and Scales Of Measurement. SHIKEN: JALT Testing \& Evaluation SIG Newsletter, 15(1), 10-14.

Chowning, J. (2009). Socratic Seminars in Science Class: Providing a Structured Format to Promote Dialogue and Understanding. Sci Teach, 76(7), 36-41.

Creswell, J. (2014). Research Design: Qualitative, Quantitative \& Mixed Methods Approaches (4th ed). London, England: Sage publication.

Dahiya, S. \& Dahiya, R., (2015). Classroom Seminar and Journal Club (CRSJC) as an Effective Teaching Learning Tool: Perceptions to Post Graduation Pharmacy Students. The Journal of Effective Teaching, 15(1), 69-83

Doane, K. \& Boyd, P. (2016). A symposium-Based Self-Directed Learning Approach to Teaching Medical Cell Biology to Medical Students. International Association of Medical Sciences Educators, 26(2), 229-237. https://doi.org/10.1007/s40670-016-0243-x

Gibson, J. (2010). Small Group Teaching in English Literature: A Good Practice Guide. In J. Gawthrope (Ed), Report Series, 23, 1-28. UK: The Higher Education Academy English Subject Centre. Retrieved from www.english.heacademy.ac.uk/archive/publications/reports/small_gp_teaching.pdf

Gray, D. (2013). Doing research in the real world (3rd Ed.). London, UK: Sage publications. 
Jonsson, A., \& Svingby, G. (2007). The Use of Scoring Rubrics: Reliability, Validity and Educational Consequences. Educational Research Review, 2(2). 130-144. https://doi.org/10.1016/j.edurev.2007.05.002

Koshy, V. (2010). Action Research for Improving Educational Practice [electronic resource]: a Step-by-Step Guide (2nd ed.). London, England: Sage publication.

Murray, J., Giesbrecht, N., \& Mosonyi, S. (2011). Enquiry, Engagement, and e-Learning: Three Perspectives on a Student-Entered, Enquiry-Based Online Course. CELT, 6, 34-40. https://doi.org/10.22329/celt.v6i0.3680

North Dakota State University (2015). Graduate Seminar Evaluation Form. Retrieved 2015, January 10 from https://www.ag.ndsu.edu/plantsciences/graduate/courses/docs790/EvaluationForm.pdf

Padgett, R., Keup, J., \& Pascarella, E. (2013). The impact of first-year seminars on college students' life-long learning orientations. Journal of Student Affairs Research and Practice, 50(2), 133-151. https://doi.org/10.1515/jsarp-2013-0011

Passarelli, A., \& Kolb, D. (2011). Using Experiential Learning Theory to Promote Student Learning and Development in Programmes of Education Abroad, University Cleveland (pp.1-37). Retrieved 2016, September 30 from https://weatherhead.case.edu/departments/organizational-behavior/workingPapers/WP-11-03.pdf

Playmouth University (2011). Lectures Seminars Experiential learning: Placements and Work-based Learning Open and Flexible Learning Group Work. Retrieved 2016, October from https://www.plymouth.ac.uk/uploads/production/document/path/1/1712/Lectures_and_Seminars.pdf

Polly, D., Frazier, J., Hopper, C., Chapman, M. \& Wells, R. (2012). Examining the Influence of a Support Seminar on Pre-service Teachers' Preparedness for Student Teaching. School-University Partnerships, 5(1), 102-107.

Randell, A. (2013, August 15). Five Awesome Reasons to Use Google Forms. Retrieved 2016, December 10 fromhttp://www.makeuseof.com/tag/5-awesome-reasons-to-use-google-forms

Spruijt, A., Wolfhagen, I., Bok H., Schuurmans, E., Scherpbier, A., Beukelen, P., \& Jaarsma, D. (2013). Teachers' perceptions of aspects affecting seminar learning: a qualitative study. BMC Medical Education, 13(22), 1-10. https://doi.org/10.1186/1472-6920-13-22

University of Illinois (2012). Graduate Student Research Seminars and Annual Review. Retrieved 2015, September 10 from www.life.illinois.edu/mcb/595/articles/595_info.pdf

Weber, R., Gabbert, A., Kropp, J., \& Pynes, P. (2007). Creating the Teaching Professor: Guiding Graduate Students to Become Effective Teachers. The Journal of Scholarship of Teaching and Learning, 7(1), 45-63.

Yildirim, N. (2010). Increasing Effectiveness of Strategic Planning Seminars through Learning Styles. Australian Journal of Teacher Education, 35(4), 12-24. https://doi.org/10.14221/ajte.2010v35n4.2

\section{Appendix A: Course Structure (Syllabus)}

\begin{tabular}{|l|}
\hline Genres of Children's Literature \\
\hline Week I: Introduction to Children's Literature (Genre of Children's Literature) \\
\hline Week II: Traditional \& Contemporary Poetry \\
\hline Week III: Folk Tales \\
\hline Week IV: Fairy Tales \\
\hline Week V: Fairy Tales \\
\hline Week VI: Fantasy \\
\hline Week VII: Fantasy \\
\hline Week VIII: Fables \\
\hline Week IX: Allegorical Stories \\
\hline Week X: Adventure Stories \\
\hline Week XI: Adventure Stories \\
\hline Week XII: Biographies \\
\hline
\end{tabular}




\section{Week XIII: Realistic Fiction}

Week XIV: Realistic Fiction

Week XV: Samples of Omani Children's Literature

Week XVI: Final Exam

\section{Appendix B: Seminar Rubric}

Evaluator:

Children Literature

Seminar Evaluation Form

Speaker:

\begin{tabular}{|c|c|c|c|}
\hline No & Criteria & Comment & Mark/10 \\
\hline 1 & $\begin{array}{l}\text { Subject Matters } / 3 \\
\cdot \quad \text { Definition and types } \\
\text { Origins } \\
\text {. } \quad \text { Characteristics }\end{array}$ & & \\
\hline 2 & \begin{tabular}{ll}
\multicolumn{2}{l}{ Presentation $/ 4$} \\
$\cdot$ & Techniques \\
$\cdot$ & Organization \\
$\cdot$ & Language \\
. & Visual aids
\end{tabular} & & \\
\hline 3 & $\begin{array}{l}\text { Questions and Discussion } / 3 \\
\cdot \quad \text { Leading questions } \\
\cdot \quad \text { Promoting questions } \\
\text {. } \quad \text { Handling questions }\end{array}$ & & \\
\hline \multicolumn{4}{|c|}{ Overall Comments } \\
\hline & & & Total Mar \\
\hline
\end{tabular}

Adapted from NDSU Plant Science Course Seminar Evaluation Form (2015).

\section{Copyrights}

Copyright for this article is retained by the author(s), with first publication rights granted to the journal.

This is an open-access article distributed under the terms and conditions of the Creative Commons Attribution license (http://creativecommons.org/licenses/by/4.0/). 